\title{
Endometrial epithelial cells are potent producers of tracheal antimicrobial peptide and serum amyloid $A 3$ gene expression in response to $E$. coli stimulation
}

\author{
Aspinas Chapwanya ${ }^{\mathrm{a}, \mathrm{d}}$, Kieran G. Meade ${ }^{\mathrm{b}}$, Michael L. Doherty ${ }^{\mathrm{c}}$, John J. Callanan ${ }^{\mathrm{c}}$, Cliona \\ O'Farrelly ${ }^{\text {a, }}$ \\ ${ }^{a}$ Comparative Immunology Group, School of Biochemistry and Immunology, Trinity College, Dublin 2 , \\ Ireland \\ ${ }^{\mathrm{b}}$ Animal \& Grassland Research and Innovation Centre, Teagasc, Co. Meath, Ireland \\ ${ }^{\mathrm{c}}$ UCD School of Veterinary Medicine, Dublin 4, Ireland \\ ${ }^{\mathrm{d}}$ Department of Production Animal Studies, Faculty of Veterinary Science, University of Pretoria, \\ Onderstepoort, Pretoria 0014, South Africa
}

\begin{abstract}
Endometrial epithelial cells play a critical role in mediating inflammatory mechanisms key to bacterial clearance and tissue re-modelling postpartum. This study characterised innate immune gene expression by bovine endometrial epithelial cells from three animals in response to Escherichia coli, a common cause of bovine uterine disease. Expression of key innate immune genes, encoding Toll-like receptor 4 (TLR4), the transcription factor $N F k B 1$, the chemokine interleukin 8 (IL8), inflammatory cytokines (interleukins $I L 1 \beta, I L 6$; tumour necrosis factor, $T N F$ ), $\beta$-defensins (lingual antimicrobial peptides $L A P$, tracheal antimicrobial peptide $T A P$ ) and acute phase proteins (haptoglobin, $H P$; serum amyloid A, $S A A 3$ ) was examined in endometrial epithelial cells stimulated with $E$. coli for 6 and $24 \mathrm{~h}$ using qRT-PCR. Expression of all genes was increased significantly $(P<0.05) 6 \mathrm{~h}$ post-stimulation. Expression of $I L 1 b, T N F$ and $S A A 3$ genes was increased by 121-, 357- and 721-fold, respectively $(P<0.05)$. Twenty four hours post-stimulation, ILIb, IL6,IL8,TNF and $L A P$ gene expression was decreased compared to $6 \mathrm{~h}$, whereas TAP and $S A A 3$ expression was further increased to 209 - and 3452-fold $(P<0.05)$. E. coli driven expression of immune effector genes demonstrates potent immune, antimicrobial and regulatory capacity of endometrial epithelial cells to respond to this pathogen.
\end{abstract}

\section{Keywords}

Acute phase proteins; Endometrial epithelial cells; Innate immunity; Antimicrobial peptides; Quantitative real time polymerase chain reaction

\section{Introduction}

Infection of the uterus is an important cause of infertility in dairy cows (LeBlanc et al., 2002, Muskens et al., 2011 and Williams et al., 2005) and dysregulated inflammatory responses to contaminating bacteria are thought to underlie endometritis and sub-fertility (Gabler et al., 2011). Gram negative coliform bacteria induce acute inflammation of the endometrium, and 
Escherichia coli is the predominant pathogen isolated from animals affected with uterine disease and epithelial cells are thought to play a key role in local innate immunity. Innate immunity is the first line of host defence against invading pathogens ( Medzhitov and Janeway, 2000, O’Neill, 2001, O’Neill, 2005 and Palsson-McDermott and O’Neill, 2007). We have recently characterised innate immune gene expression in uterine tissue from cows that had experienced endometrial bacterial invasion and inflammation postpartum ( Chapwanya et al., 2009 and Chapwanya et al., 2012). Genes encoding defence molecules such as antimicrobial peptides (AMPs) and acute phase proteins (APPs) were expressed in endometrial biopsies.

Endometrial epithelial cells line the entire uterine mucosal surface, forming a physical barrier protecting the host from pathogen invasion as well as contributing to local innate immunity (Herath et al., 2006b, Soboll et al., 2006 and Wira et al., 2005). In addition, these endometrial epithelial cells interact, recognise and respond to pathogens via surface receptors such as TLRs in the bovine uterus (Davies et al., 2008). Epithelial cells also mount a robust response to the $E$. coli ligand LPS, primarily producing both $L A P$ and TAP AMPs after $24 \mathrm{~h}$ of in vitro culture. Human endometrial epithelial cells also secrete chemokines and cytokines that attract and activate other immune cells ( Fahey et al., 2005 and Quayle, 2002), and there is some evidence that they present antigens to T-lymphocytes (Wira and Rossoll, 1995). After calving, upon sensing microbial pathogens, endometrial epithelial cells contribute to local inflammation by initiating the innate immune responses via IL-1, TNF- $\alpha$ and IL-6 cytokines ( Eriksson et al., 2006 and Hirota et al., 2006). TLR4 is the principal recognition molecule through which endometrial epithelial cells detect the LPS ligand of the Gram negative bacterial pathogen E. coli (Sheldon et al., 2010). In this study, we aimed to examine acute phase protein expression by bovine endometrial cells. In cattle, two classes of APPs can be induced: type 1 APPs including SAA are induced by IL-6-type cytokines, while type 2 APPs (e.g. HP) are induced by IL-1 ( Baumann and Gauldie, 1994 and Streetz et al., 2001). APPs are traditionally thought to be derived exclusively from the liver during the acute phase response (APR) to infection, injury or inflammation (Huntoon et al., 2008). APPs have been detected in serum of postpartum cows showing signs of uterine disease ( Huzzey et al., 2009 and Sheldon et al., 2001) as well as in clinical cases of acute mastitis (Eckersall et al., 2006). During the mammalian APR in vivo, inflammation and systemic induction of HP expression are correlated (Wang et al., 2001). Local expression of APPs by endometrial cells could augment systemic production during disease and would bolster their advocacy as potential diagnostic markers ( Chan et al., 2010 and Huzzey et al., 2009).

\section{Methods and materials}

\subsection{Bovine endometrial epithelial cells}

Uteri from three non-pregnant cows were collected at a local abattoir immediately after slaughter and kept on ice until further processing in the laboratory. These animals had no evidence of genital disease based on visual inspection. The physiological stage of the reproductive cycle for each genital tract was determined by observation of the uterine and ovarian structures, particularly the corpus luteum (CL) (Ireland et al., 1980). Three tracts with an early CL, indicative of stage 1, were selected for endometrial tissue culture. Cell isolation was performed as previously described using only the endometrium from the horn ipsilateral to the CL while 
maintaining sterility at all times (Herath et al., 2006b). Briefly, before dissection the uterine body was rinsed with $70 \% \mathrm{EtOH}$ before opening the ipsilateral horn. The endometrial surface was then rinsed with PBS (Sigma - D8537) supplemented with 1\% Pen/Strep (Sigma - P4458) and 1\% Amphotericin B (Sigma - A2942). The endometrium was dissected from the horn, cut into strips and placed in Hanks Balanced Salt Solution (HBSS, Sigma - H6648) supplemented with 1\% Pen/Strep (Sigma - P4458) and 1\% Amphotericin B (Sigma - A2942). The strips were then washed in fresh HBSS prior to being sliced into smaller pieces measuring approximately $3-$ $5 \mathrm{~mm}^{3}$ followed by a further wash in HBSS. After incubation for $10 \mathrm{~min}$ at $37^{\circ} \mathrm{C}$, the HBSS was decanted and the tissue digested in $25 \mathrm{ml}$ sterile filtered digestive solution (50 mg trypsin III (Roche, Lewes, UK), $50 \mathrm{mg}$ collagenase II (Sigma, Poole, UK), $100 \mathrm{mg}$ BSA (Sigma), and $10 \mathrm{mg}$ DNase I (Sigma) in $100 \mathrm{ml}$ phenol-red-free Hanks Balanced Salt Solution (HBSS; Sigma). After $1 \mathrm{~h}$ incubation in a gently agitating water bath at $37^{\circ} \mathrm{C}$, the cell suspension was filtered through a $40-\mu \mathrm{m}$ mesh (Fisher Scientific, Loughborough, UK) to remove undigested material and made up to $40 \mathrm{ml}$ with HBSS solution (HBSS (Sigma - H6648) supplemented with $10 \%$ heat inactivated FBS, (PAA - A15-104). The suspension was centrifuged at $700 \times g$ for $7 \mathrm{~min}$, resuspended in $5 \mathrm{ml}$ of sterile water $\left(37^{\circ} \mathrm{C}\right)$, and vortexed for no longer than $30 \mathrm{~s}$, to lyse of red blood cells. HBSS solution was added up to $40 \mathrm{ml}$ and the suspension centrifuged at $700 \times \mathrm{g}$ for $7 \mathrm{~min}$. Finally, the cells were re-suspended in RPMI 1640 medium containing $1 \%$ Pen/Strep (Sigma - P4458) and 1\% Amphotericin B (Sigma - A2942). The cells were plated at a density of $6 \times 10^{5}$ cells in $2 \mathrm{ml}$ per well using 24 -well plates (Nunc, Rochester, NY, USA). Epithelial cells were allowed to adhere to the plate for $17 \mathrm{~h}$ and the medium containing the stromal cells was removed. Epithelial cells were identified using morphology, and the purity $(>95 \%)$ as determined by microscopy and differential production of prostaglandins (stromal cells do not produce prostaglandin F2 $\alpha$ ) (Herath et al., 2006b). The culture medium was changed every $48 \mathrm{~h}$ until the cells reached confluence. All cultures were maintained at $37{ }^{\circ} \mathrm{C}, 5 \% \mathrm{CO}_{2}$ in air, in a humidified incubator.

\section{2. $E$. coli bacterial cells}

The strain of E. coli (MS360) used in these experiments had been isolated 7 days postpartum from the uterus of a cow with metritis and pyrexia. The MS360 isolate was identified using standard laboratory techniques as a B1 strain of pathogenic E. coli (EnPEC), serotype O73:H16, which adhered to and invaded bovine endometrial epithelial cells in vitro (Sheldon et al., 2010). Briefly, MS360 was grown in LB broth (Sigma) at $37^{\circ} \mathrm{C}$ overnight and the number of colony forming units determined by serial dilution in PBS and plate count. The E. coli were heat killed (HKEC) at $80^{\circ} \mathrm{C}$ for 30 min and diluted to a final working concentration equivalent to $10^{6} \mathrm{CFU} / \mathrm{ml}$ in endometrial cell culture media. The optimum concentration of HKEC was previously determined for epithelial cells (Herath et al., 2006a).

\subsection{Stimulation of bovine endometrial epithelial cells}

To examine production of AMP and APP molecules by endometrial epithelial cells, $90 \%$ confluent cells (cell density of $6 \times 10^{5}$ ) were stimulated for 6 and $24 \mathrm{~h}$ with heat-killed $E$. coli at $10^{6}$ colony forming units (CFU) per ml of culture medium in 24-well tissue culture plates (Helena Bioscience, UK). Control cells were treated with complete medium alone. The 
endometrial cells were preserved in RNALater (Qiagen) and stored at $-80{ }^{\circ} \mathrm{C}$ until required for RNA extraction and qRT-PCR analysis.

\subsection{RNA extraction, quantification and cDNA synthesis}

Total RNA was extracted from the endometrial cells using the Qiagen RNeasy ${ }^{\circledR}$ method (Qiagen Ltd.) and DNase treated according to the manufacturer's instructions. To ensure integrity and stability of RNA samples, yield and quality were assessed using an Agilent 2100 Bioanalyzer (Agilent Technologies). One microgram of total RNA from each sample was reverse transcribed into cDNA using an OmniScript III ${ }^{\circledR}$ first-strand synthesis kit using oligo (dT) primers (Invitrogen Ltd., Paisley, UK). The cDNA was quantified using a Nanodrop ${ }^{\mathrm{TM}}$ spectrophotometer, and then diluted to $40 \mathrm{ng} / \mu \mathrm{l}$ for qRT-PCR analyses.

\subsection{Normaliser gene selection and qRT-PCR}

Gene specific primers for real time qRT-PCR were designed, where possible to span introns, using Primer3 software (Rozen and Skaletsky, 2000) and commercially synthesised (Invitrogen Ltd., Paisley, UK). Primer sequences used in this study were published previously (Chapwanya et al., 2009 and Whelehan et al., 2011). Real-time qRT-PCR analyses were performed with $12.5 \mu$ l of quantitative PCR mix (Brilliant ${ }^{\circledR}$ SYBR $^{\circledR}$ Green Master Mix) which contains SureStart ${ }^{\circledR}$ Taq DNA polymerase, $\mathrm{MgCL}_{2}$, nucleotides, optimised reaction buffer components and SYBR $^{\circledR}$ Green I dye (Stratagene: www.stratagene.com), $2.5 \mu$ l of the forward together with $2.5 \mu \mathrm{l}$ of the reverse primer (final concentrations 300,600 or $900 \mathrm{nM}$ ), and $80 \mathrm{ng}$ of cDNA template making a total of $25 \mu \mathrm{l}$ per reaction. All reactions were performed in duplicate. A no template control (NTC) was run for all genes to ensure that the amplified product is due to the bovine endometrial epithelial cDNA and not gDNA contamination. All gene amplifications were normalised to $G A P D H$, selected as most stable gene across all samples from a panel of potential reference genes ( $A C T B, G A P D H, M R P S 6, R P S 9$, MRPS15, H3F3A, PPIA) analysed using GeNORM (Vandesompele et al., 2002).

\subsection{Statistical analysis}

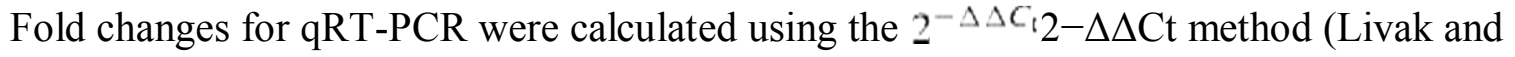
Schmittgen, 2001) as the expression of the gene of interest in stimulated endometrial cells, compared to expression of the normaliser gene $(G A P D H)$, and shown relative to the mean in non-stimulated cells. Statistical analyses were performed on normalised $C_{\mathrm{t}}$ values between stimulated and unstimulated cells from the same animal using a paired Student's $t$-test (see Table $1)$. 
Table 1. Gene expression in primary endometrial epithelial cells from three animals stimulated with heatkilled $E$. coli for 6 and $24 \mathrm{~h}$. Fold changes indicate changes in mRNA concentration in the stimulated cells relative to unstimulated control cells.

\begin{tabular}{|c|c|c|c|c|c|c|c|c|c|c|}
\hline \multirow[t]{2}{*}{ Gene class } & \multirow{2}{*}{$\begin{array}{l}\text { Gene } \\
\text { name }\end{array}$} & \multicolumn{2}{|c|}{ Cow 1} & \multicolumn{2}{|c|}{ Cow 2} & \multicolumn{2}{|c|}{ Cow 3} & \multicolumn{2}{|c|}{$\begin{array}{l}\text { Average fold } \\
\text { change }\end{array}$} & $P$ values \\
\hline & & $6 \mathrm{~h}$ & $24 \mathrm{~h}$ & $6 \mathrm{~h}$ & $24 \mathrm{~h}$ & $6 \mathrm{~h}$ & $24 \mathrm{~h}$ & $6 \mathrm{~h}$ & $24 \mathrm{~h}$ & $6 \mathrm{~h} \quad 24 \mathrm{~h}$ \\
\hline $\begin{array}{l}\text { Pathogen recognition } \\
\text { receptor }\end{array}$ & TLR4 & 1.46 & 50.56 & 4.27 & 5.68 & 5.19 & 11.12 & 4 & 22 & 0.0990 .053 \\
\hline Transcription factor & $N F k B 1$ & 2.08 & 1.46 & 2.13 & 1.44 & 2.26 & 1.53 & 2 & 1.5 & 0.0010 .002 \\
\hline \multirow[t]{2}{*}{ Chemokine } & IL8 & 29.55 & 20.97 & 21.48 & 14.22 & 5.80 & 2.47 & 19 & 13 & 0.0320 .079 \\
\hline & $I L 1 \beta$ & 151.69 & 11.79 & 137.19 & 11.20 & 73.52 & 2.35 & 121 & 8 & 0.0020 .069 \\
\hline \multirow[t]{2}{*}{ Cytokines } & IL6 & 12.64 & 5.88 & 12 & 4.33 & 25.99 & 7.19 & 17 & 6 & 0.0070 .008 \\
\hline & $T N F$ & 929.30 & 237.21 & 79.07 & 92.73 & 61.39 & 179.77 & 357 & 170 & 0.0280 .003 \\
\hline \multirow{2}{*}{$\begin{array}{l}\text { Antimicrobial } \\
\text { peptides }\end{array}$} & $L A P$ & 48.50 & 16.45 & 70.03 & 10.02 & 69.07 & 23.18 & 63 & 17 & 0.0010 .008 \\
\hline & $T A P$ & 67.65 & 306.55 & 96.34 & 219.79 & 26.72 & 101.83 & 64 & 209 & 0.0090 .004 \\
\hline \multirow{2}{*}{ Acute phase proteins } & $H P$ & 3.96 & 5.03 & 3.46 & 3.75 & 2.65 & 2.52 & 3 & 4 & 0.0100 .023 \\
\hline & $S A A 3$ & 1865 & 7526 & 965 & 4624 & 438 & 413 & 721.5 & 3451.8 & 0.0040 .013 \\
\hline
\end{tabular}

\section{Results and discussion}

E. coli induced rapid and consistent inflammatory gene expression in primary endometrial epithelial cell cultures from all 3 animals. Although TLR4 gene expression was induced in response to $E$. coli (by 4 -fold at $6 \mathrm{~h}$ and by 22 -fold at $24 \mathrm{~h}$; relative to unstimulated controls); values were not statistically significant (Fig. $1 ; P=0.099$ and 0.053 , respectively). The activation of common inflammatory markers was evidenced by a significant increase in IL6 (Fig. 1, 17-fold, $P=0.007$ ). IL 8 gene expression was also significantly increased by 19 -fold $(P=0.032)$, showing an important capacity of epithelial cells to chemotactically attract neutrophils into the uterus - an important defence against invading bacteria. The early increase in expression of $I L-8$ (19-fold after $6 \mathrm{~h}$ and 13 -fold after $24 \mathrm{~h} ; P<0.05$, Fig. 1 ) demonstrates the ability of these cells to detect and respond to bacterial antigens, in agreement with earlier work by our group ( Chapwanya et al., 2009 and Chapwanya et al., 2012), and by others ( Davies et al., 2008 and Palffy et al., 2009). Twenty four hours post-stimulation, gene expression for IL8 and the inflammatory cytokines have reduced to levels less than those after $6 \mathrm{~h}$ (Fig. 1). Nevertheless, expression levels for IL6 as well as NFkBI and TNF are significant raised compared to unstimulated controls at 1.5-, 6- and 170-fold. The consistently elevated expression of $T N F$ may identify this cytokine as a stable marker of unresolved inflammation during uterine infection in vivo. This concurs with recent literature which detected elevated TNF expression in endometrial epithelium from cows with subclinical and clinical metritis (Fischer et al., 2010). 


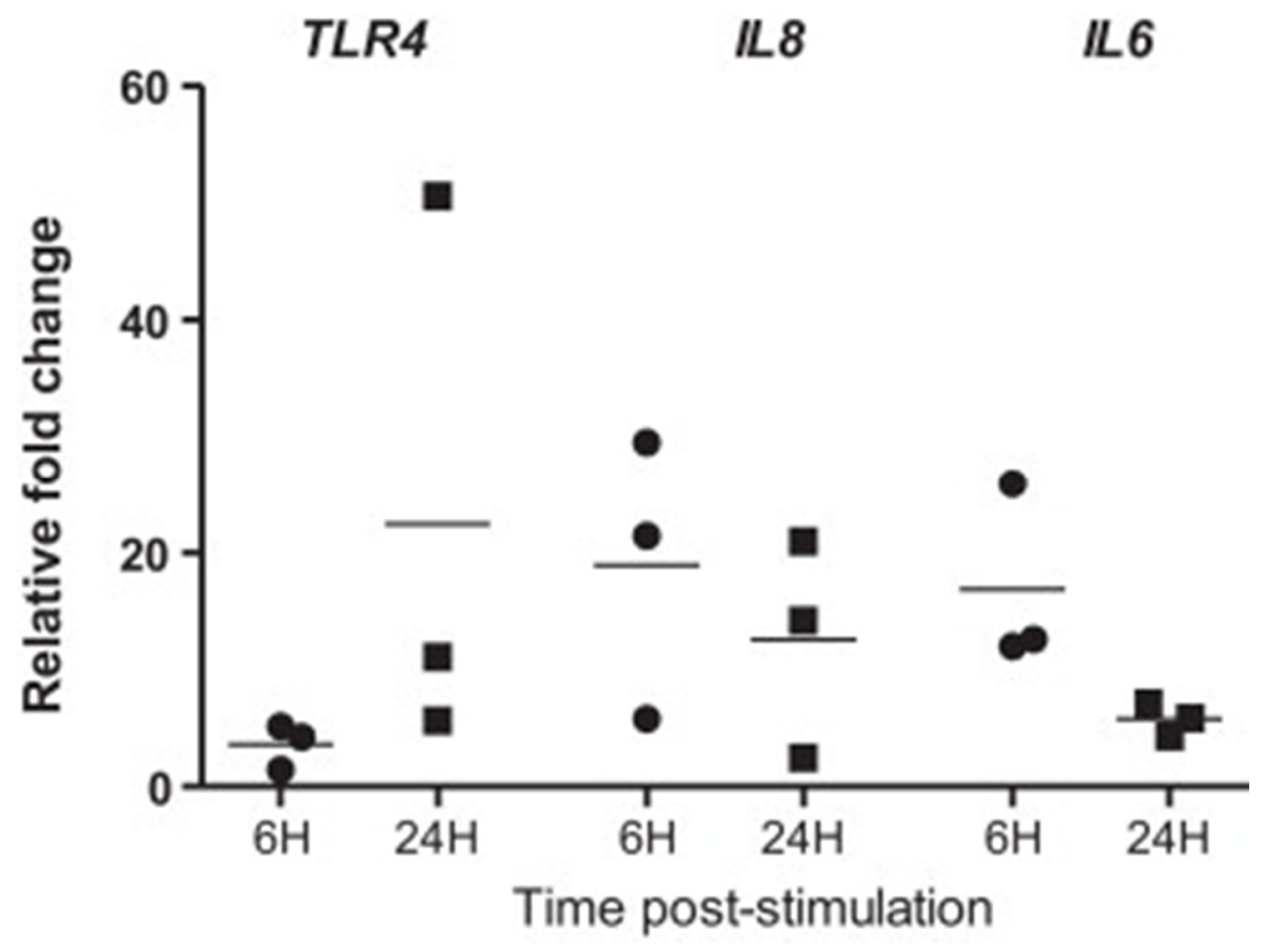

Fig. 1. TLR, IL8 and IL6 gene expression profiles from qRT-PCR analyses of endometrial epithelial cells from postpubertal non-pregnant animals stimulated with heat-killed $E$. coli $(n=3)$. All $C_{\mathrm{t}}$ values were normalised to expression of the reference $G A P D H$ gene relative to unstimulated (control) cells from the same animal. Each point on the graph represents the mean fold change in gene expression. The circles represent expression $6 \mathrm{~h}$ and the squares $24 \mathrm{~h}$ post-stimulation.

Results from the antimicrobial peptide gene expression showed a gene-specific response. High levels of lingual antimicrobial peptide $(L A P)$ and tracheal antimicrobial peptide $(T A P)$ gene expression were both detected at $6 \mathrm{~h}$ post-stimulation with $E$. coli (63- and 64-fold, respectively, $P<0.01$ ). However, $24 \mathrm{~h}$ post-stimulation, $L A P$ gene expression had reduced to 4-fold (Fig. 2), $T A P$ expression continued to increase to 209 -fold $(P=0.004$, Fig. 2$)$. AMPs are induced in response to infection or injury via signalling mediated by TLRs or release of pro-inflammatory cytokines ( Selsted and Ouellette, 2005 and Sorensen et al., 2008), and these results suggest that epithelial cells are the main producers of TAP in the endometrium and that they are highly sensitive to E. coli stimulation. Similar to previous studies (Davies et al., 2008), LAP and TAP gene expression in the endometrial epithelial cells indicates that these AMPs are key defence molecules in the uterus against infectious pathogens such as E. coli.

Gene expression of two acute phase protein (APP) genes - HP and $S A A 3$, was also examined in endometrial epithelial cells. While the gene expression for $H P$ was induced by only 3 -fold after $6 \mathrm{~h}, S A A 3$ was increased by 721 -fold $(P=0.004$, Fig. 3$)$ at the same time point. Expression of the $S A A 3$ gene was significantly increased by 3452 -fold after $24 \mathrm{~h}(P<0.05$, Fig. 3$)$. These results show that endometrial epithelial cells are potent producers of specific APPs in response to 


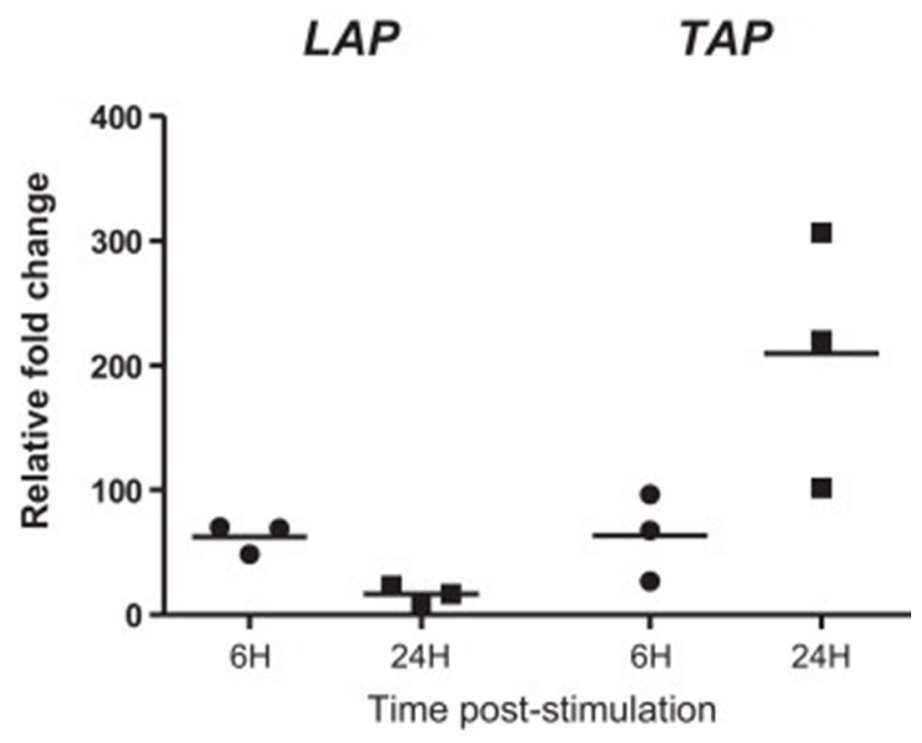

Fig. 2. Antimicrobial peptide genes $-L A P$ and $T A P$ expression profiles from qRT-PCR analyses of endometrial epithelial cells from post-pubertal non-pregnant animals stimulated with $\operatorname{E}$. coli $(n=3)$. All $C_{\mathrm{t}}$ values were normalised to expression of the reference gene GAPDH relative to unstimulated (control) cells from the same animal. Each point on the graph represents the mean fold change in gene expression. The circles represent expression $6 \mathrm{~h}$ and the squares $24 \mathrm{~h}$ post-stimulation.

E. coli infection. It is well documented that HP and SAA APPs increase substantially in serum of animals with endometritis ( Chan et al., 2010 and Huzzey et al., 2009); because SAA plays an important role in the host's innate immune response (Urieli-Shoval et al., 2000), APP production may have a direct influence on the outcome of endometrial infection.
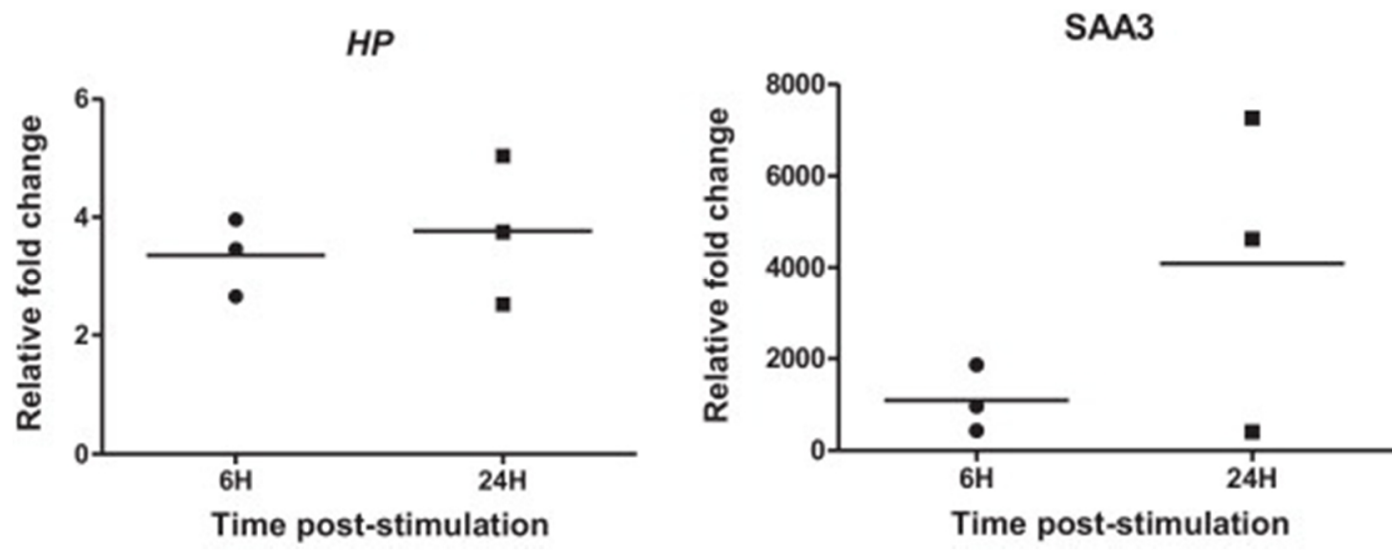

Fig. 3. (a) $H P$ and (b) $S A A 3$ gene expression profiles from qRT-PCR analyses of endometrial epithelial cells from post-pubertal non-pregnant animals stimulated with heat-killed $E$. coli $(n=3)$. All $C_{\mathrm{t}}$ values were normalised to expression of the reference $G A P D H$ gene relative to unstimulated (control) cells from the same animal. Each point on the graph represents the mean fold change in gene expression. The circles represent expression $6 \mathrm{~h}$ and the squares $24 \mathrm{~h}$ post-stimulation. 
Owing to their location, endometrial epithelial cells are the first cells to contact, recognise and respond to microbial insults (Fahey et al., 2006). Since bacterial infection, particularly by E. coli, of the female genital tract is common in cattle after parturition causing considerable disease, subfertility and occasionally death ( LeBlanc, 2008, Sheldon et al., 2009 and Sheldon et al., 2010); there is much interest in the host-pathogen interaction at the mucosal surface. Previous studies, including some by our group, have examined expression of key innate immune genes after calving in endometrial biopsies which contain several cell types - both immune and non-immune ( Chapwanya et al., 2009, Chapwanya et al., 2010 and Martins et al., 2011). The particularly high expression of specific classes of immune effector genes, even in healthy animals, gave rise to speculation regarding the source of AMPs and APPs, the latter which would normally be thought of as hepatically derived. Local expression of these molecules could have important implications for their potential use as diagnostic biomarkers of uterine infection.

In summary, in this in vitro study, we have shown that endometrial epithelial cells are immunocompetent and respond to heat-killed $E$. coli in a gene specific manner. These cells express the inflammatory cytokine $T N F$, the AMP gene $T A P$, and the APP gene $S A A 3$ at particularly high levels in response to $E$. coli stimulation. Because APPs were proposed as diagnostic markers of uterine infection, additional studies are warranted to better understand localised endometrial expression of $S A A 3$ and the potential usefulness of SAA as a sensitive diagnostic for E. coli infection in cattle.

\section{Conflict of interest}

The authors declare no conflict of interest.

\section{References}

Baumann, H., Gauldie,J., 1994. The acute phase response. Immunol. Today 15, 74-80.

Chan, J.P., Chang, C.C., Hsu, W.L., Liu, W.B., Chẹn, T.H., 2010. Association of increased serum accute-phase protein concentrations with reproductive performance in dairy cows with postpartum metritis. Vet. Clin. Pathol. 39 (1),
$72-78$.

Chapwanya, A., Meade, K.G., Doherty, M.L., Callanan, J.J., Mee, J.F., O’Farrelly, C, 2009. Histopathological and molecular evaluation of Holstein-Friesian cows postpartum: toward an improved understanding of uterine innate immunity. Theriogenology 71 (9), 1396-1407.

Chapwanya, A., Meade, K.G., Foley, C, Narciandi, F., Evans, A.C., Doherty, MX., Callanan, J.J., O’Farrelly, C, 2012. The postpartum endometrial inflammatory response: a normal physiological event with potential implications for bovine fertility. Reprod. Fertil. Dev., http://dx.doi.org/10.1071/RD11153.

Chapwanya, A., Meade, K.G., Narciandi, F., Stanley, P., Mee, J.F., Doherty, MX., Callanan, J.J., O’Farrelly, C, 2010. Endometrial biopsy: a valuable clinical and research tool in bovine reproduction. Theriogenology 73 '(7), 988-994.

Davies, D., Meade, K.G., Herath, S., Eckerșall, P.D., Gonzalez, D., White, J.O., Conlan, R.S., O’Farrelly, C, Sheldon, I.M., 2008. Toll-like receptor and antimicrobial peptide expression inthe bovine endometrium. Reprod. Biol. Endocrinol. 6(1), 53.

Eckersall, P.D., Young, F.J., Nolan, A.M., Knight, C.H., McComb, C, Water-ston, M.M., Hogarth, C.J., Scott, E.M. Fitzpatrick,JX., 2006. Acute proteins in bovine milk in an experimental model of Staphylococcus aureus subclinical mastitis. J. Dairy Sci. 89,1488-1501.

Eriksson, M., Meadows, S.K., Basu, S., Mselle, T.F., Wira, C.R., Sentman, C.L., 2006. TLRs mediate IFN-gamma production by human uterine NK cells in endometrium. J. Immunol. 176 (10), 6219-6224. 
Fahey, J.V., Schaefer, T.M., Channon, J.Y., Wira, C.R., 2005. Secretion of cytokines and chemokines by polarized human epithelial cells from the female reproductive tract. Hum. Reprod. 20 (6), 1439-1446.

Fahey, J.V., Wallace, P.K., Johnson, K., Guyre, P.M., Wira, C.R., 2006. Antigen presentation by human uterine epithelial cells to autologous T cells. Ám.J. Reprod. Immunol. 55 (1), 1-11.

Fischer, C, Drillich, M., Odau, S., Heuwieser, W., Einspanier, R., Gabler, C,

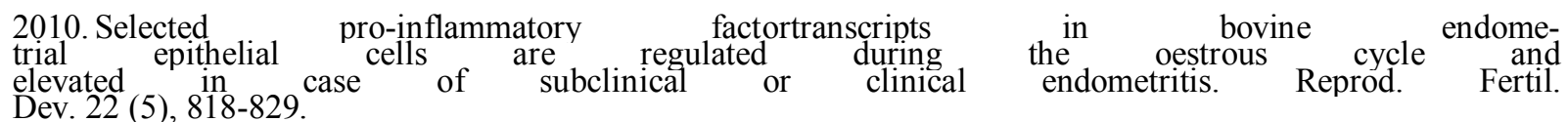

Gabler, C, Fischer, C, Drillich, M., Einspanier, R., Heuwieser, W., 2011. Time-dependent mRNA expression of selected pro-inflammatory factors in the endometrium of primiparous cows postpartum. Reprod. Biol. Endocrinol. 8,152.

Herath, S., Dobson, H., Bryant, C.E. Sheldon, I.M., 2006a. Use of the cow as a large animal model of uterine infection and immunity. J. Reprod. Immunol.' 69 (1), 13-22.

Herath, S., Fischer, D.P., Werling, D. Williams, E.J., Lilly, S.T., Dobson, H., Bryant, C.E., Sheldon, I.M., 2006b. Expression and function of Toll-like receptor 4 in the endometrial cells of the uterus. Endocrinology 147 (1), 562-570.

Hirota, Y., Osuga, Y., Koga, K., Yoshino, O., Hirata, T., Morimoto, C, Harada, M., Takemura, Y., Nose, E., Yano, T., Tsutsumi, O., Taketani, Y., 2006. The expression and possible roles of chemokine CXCL11 and its receptor CXCR3 in the human endometrium. J. Immunol. 177 (12), 8813-8821.

Huntoon, K.M., Wang, Y., Eppolito, C.A., Barbour, K.W., Berger, F.G., Shrikant, PA, Baumann, H., 2008. The acute phase protein haptoglobin regulates host immunity. J. Leukoc. Biol. 84 (1), 170-181.

Huzzey,J.M., Duffield, T.F., LeBlanc, S.J., Veira, D.M., Weary, D.M., von Key-serlingk, M.A., 2009. Short communication: haptoglobin as an early indicator of metritis. J. Dairy Sci. 92 (2), 621-625.

Ireland, J.J., Murphee, R.L., Coulson, P.B., 1980. Accuracy of predicting stages of bovine estrous cycle by gross appearance of the corpus luteum.J. Dairy Sci. 63 (1), 155-160.

LeBlanc, S.J., 2008. Postpartum uterine disease and dairy herd reproductive performance: a review. Vet. J. 176(1), $102-114$

LeBlanc, S.J., Duffield, T.F., Leslie, K.E., Batemạ, K.G., Keefe, G.P., Walton, J.S., Johnson, W.H., 2002. Defining and diagnosing postpartum clinical endometritis and its impact on reproductive performance in dairy cows. $J$. Dairy Sci. 85 (9), 2223-2236.

Livak, K.J., Schmittgen,T.D., 2001. Analysis of relative gene expression data using real-time quantitative PCR and the 2(-Delta Delta C(T)) method. Methods 25 (4), 402-408.

Martins, T.D., Paixao, T.A., Costa, E.A., Pires, A.D., Santos, R.L., Borges, A.M.,

2011. Postpartum toll-like receptors and beta-defensin $\quad 5 \quad$ mRNA levels in the endometrium of Holstein cows. Vet. Immunol. Immunopathol.

Medzhitov, R., Janewayjr., C, 2000. Innate immune recognition: mechanisms and pathways. Immunol. Rev. 173, 89-97.

Muskens, J., van Maanen, C, Mars, M.H., 2011. Dairy cows with metritis: Coxiella burnetii test results in uterine, blood and bulk milk samples. Vet. Microbiol. 147 (1-2), 186-189. O'Neill, L, 2001. Specificity in the innate response: pathogen recognition by Toll-like receptor combinations. Trends Immunol. 22 (2), 70. O’Neill, LA, 2005. Immunity's early-warning system. Sci. Am. 292 (1), 24-31.

Palffy, R., Gardlik, R., Behuliak, M., Kadasi, L, Turna, J., Celec, P., 2009. On the physiology and pathophysiology of antimicrobial peptides. Mol. Med. 15 (1-2), $51-59$.

Palsson-McDermott, E.M., O’Neill, LA., 2007. Building an immune system from nine domains. Biochem. Soc. Trans. 35 (Pt 6), 1437-1444.

Quayle, A.J., 2002. The innate and early immune response to pathogen challenge in the female genital tract and the pivotal role of epithelial cells. J. Reprod. Immunol. 57 (1-2), 61-79. Rozen, S., Skaletsky, H., 2000. Primer3 on the WWW for general users and for biologist programmers. Methods Mol. Biol. 132,365-386. Selsted, M.E.,

Ouellette,A.J., 2005. Mammalian defensins in the antimicrobial immune response. Nat. Immunol. 6 (6), $551-557$.

Sheldon, I.M., Cronin, J., Goetze, L, Donofrio, G., Schuberth, H.J., 2009. Defining postpartum uterine disease and the mechanisms of infection and immunity in the female reproductive tract in cattle. Biol. Reprod. 81 (6), 10251032 . 
Sheldon, I.M., Noakes, D.E., Ryçroft, A., Dobson, H., 2001. Acute phase protein responses to uterine bacterial contamination in cattle after calving. Vet. Rec. 148 (6), 172-175.

Sheldon, I.M., Rycroft, A.N., Dogan, B., Craven, M., Bromfield, J.J., Chandler, A., Roberts, M.H., Price, S.B., Gilbert, R.O., Simpson, K.W., 2010. Specific strains of Escherichia coli are pathogenic forthe endometrium of cattle and cause pelvic inflammatory disease in cattle and mice. PLoS One 5 (2), e9192.

Soboll, G., Shen, L, Wira, C.R., 2006. Expression of Toll-like receptors (TLR) and responsiveness to TLR agonists by polarized mouse uterine epithelial cells in culture. Biol. Reprod. 75 (1), 131-139.

Sorensen, O.E., Borregaard, N., Cole, A.M., 2008. Antimicrobial peptides in innate immune responses. Contrib. Microbiol. 15,61-77.

Streetz, K.L., Wustefeld, T., Klein, C, Manns, M.P., Trautwein, C, 2001. Mediators of inflammation and acute phase response in the liver. Cell. Mol. Biol. 47, 66i-673.

Urieli-Shoval, S., Linke, R.P., Matzner, Y., 2000. Expression and function of serum amyloid A, a major acute-phase protein, in normal and disease states. Curr. Opin. Hematol. 7 (1), 64-69.

Vandesompele,J., De Preter, K., Pattyn, F., Poppe, B., Van Roy, N., De Paepe, A., Speleman, F., 2002. Accurate normalization of real-time quantitative RT-PCR data by geometric averaging of multiple internal control genes. Genome Biol. 3 (7), Research0034.

Wang,Y., Kinzie, E., Berger, F.G., Lim,S.K., Baumann, H., 2001.Haptoglobin, an inflammation-inducible plasma protein. Redox Rep 6,379-385.

Whelehan, C.J., Meade, K.G., Eckersall, P.D., Young, F.J., O’Farrelly, C, 2011. Experimental Staphylococcus aureus infection of the mammary gland induces region-specific changes in innate immune gene expression. Vet. Immunol. Immunopathol. 140(3-4), 181-189.

Williams, E.J., Fischer, D.P., Pfeiffer, D.U., England, G.C., Noakes, D.E., Dob-son, H., Sheldon, I.M., 2005. Clinical evaluation of postpartum vaginal mucus reflects uterine bacterial infection and the immune response in cattle. Theriogenology 63 (1), 102-117.

Wira, C.R., Grant-Tschudy, K.S., Crane-Godreau, M.A., 2005. Epithelial cells in the female reproductive tract: a central role as sentinels of immune protection. Ảm. J. Reprod. Immunol. 53 (2), 65-76.

Wira, C.R., Rossoll, R.M., 1995. Antigen-presenting cells in the female reproductive tract: influence of the estrous cycle on antigen presentation by uterine epithelial and stromal cells. Endocrinology 136(10), 4526-4534. 